\title{
Gambaran histologik ginjal tikus Wistar yang diberikan jus tomat setelah diinduksi dengan monosodium glutamat
}

\author{
Desy Togatorop ${ }^{1}$ \\ Taufiq F. Pasiak ${ }^{2}$ \\ Djon Wongkar ${ }^{3}$ \\ Martha M. Kaseke ${ }^{4}$ \\ ${ }^{1}$ Kandidat Skripsi Fakultas Kedokteran Universitas Sam Ratulangi \\ ${ }^{2}$ Bagian Ilmu Anatomi Histologi Fakultas Kedokteran Universitas Sam Ratulangi \\ Email: nafradeer0408@gmail.com
}

\begin{abstract}
Monosodium glutamate (MSG) is widely used in daily life as a flavor enhancer in food. MSG is the combination of sodium salt component and glutamic acid-L (a non essential amino acid), which is highly soluble in water. Glutamate in MSG is not bound to protein molecules, but in the free form, therefore, it will form free radicals in the body. Free radicals in the body can be neutralized by antioxidants. Tomatoes are fruits that contain several antioxidants (lycopene, vitamin $\mathrm{C}$ and vitamin $\mathrm{A}$ ). Lycopene is an antioxidant that is the highest in tomatoes. Lycopene reduces free radicals in the body by releasing up one of its electrons to bind with free radicals so the free radicals do not bind to other cells in the body and reduces the damage in the body. This study was aimed to determine the histological changes in the kidneys of Wistar rats induced by MSG, and of those that were added tomato juice. This was an experimental study with a post test only control group design. The study used 15 Wistar rats divided into three groups: group I without treatment (pellets AD II and drinking water); group II, MSG for 14 days; and group III, tomato juice and MSG for 14 days. The results showed that in both treatment groups there were visible swelling of tubular epithelial cells and narrowing of the tubular lumen, albeit, the glomeruli still looked normal.
\end{abstract}

Keywords: tomato juice, MSG, kidney damage

\begin{abstract}
Abstrak: Monosodium glutamat (MSG) banyak digunakan sebagai penyedap rasa dalam makanan. MSG adalah gabungan antara komponen garam sodium dan asam glutamat-L (suatu asam amino non esensial) yang bersifat sangat larut dalam air. Glutamat dalam MSG tidak terikat pada molekul protein melainkan dalam bentuk bebas sehingga dapat membentuk radikal bebas didalam tubuh. Radikal bebas didalam tubuh dapat dinetralisir oleh antioksidan. Tomat mengandung berbagai antioksidan (likopen, vitamin $\mathrm{C}$ dan vitamin $\mathrm{A}$ ) terutama likopen. Likopen mengurangi radikal bebas didalam tubuh dengan cara melepaskan satu elektronnya untuk berikatan dengan radikal bebas yang dapat mengurangi kerusakan yang terjadi dalam tubuh. Penelitian ini bertujuan untuk mengetahui gambaran histologik ginjal tikus wistar kelompok perlakuan I diinduksi MSG dan kelompok perlakuan II yang diberikan MSG dan jus tomat. Jenis penelitian ialah eksperimental dengan post test only control group design. Penelitian menggunakan 15 ekor tikus wistar dibagi tiga kelompok: kelompok I tanpa perlakuan (pellet AD II dan air minum); kelompok II diberi MSG selama 14 hari; dan kelompok III diberi jus tomat dan MSG selama 14 hari. Gambaran histologik ginjal pada kelompok perlakuan I (MSG) dan kelompok perlakuan II (MSG dan jus tomat) memperlihatkan glomerulus normal, pembengkakan sel epitel tubuli, dan penyempitan lumen tubuli. Tidak tampak perbedaan nyata antara kedua kelompok.
\end{abstract}

Kata kunci: jus tomat, MSG, kerusakan ginjal 
Monosodium glutamat (MSG) sering digunakan sebagai penyedap rasa didalam masakan di kehidupan sehari hari. Monosodium glutamat pada awalnya merupakan asam glutamat yang didapatkan dari sejenis rumput laut bernama Laminaria japonica.

MSG mengandung garam sodium yang berasal dari asam glutamat. Garam sodium ini dapat meningkatkan cita rasa dari suatu makanan sehingga dapat meningkatkan selera. $^{2}$ Konsumsi MSG di Indonesia meningkat dari 100.568 ton pada 1998 menjadi 122.966 ton pada 2004 atau diperkirakan peningkatan konsumsi sebesar $1,53 \mathrm{~g} /$ orang/hari. Negara yang paling sedikit mengonsumsi MSG yaitu Amerika Serikat, dan yang paling banyak yakni Cina, sedangkan di Indonesia, sekitar $77,8 \%$ populasi yang mengonsumsi $\mathrm{MSG}^{3}$

MSG merupakan gabungan antara komponen garam sodium dan asam glutamat-L (suatu asam amino non esensial) yang bersifat sangat larut dalam air dan akan berdisosiasi menjadi kation garam sodium dan anion asam glutamat. ${ }^{4}$ Glutamat didalam MSG tidak terikat pada molekul protein melainkan dalam bentuk bebas sehingga dapat membentuk radikal bebas. Konsumsi MSG secara berlebihan dapat menyebabkan terbentuknya radikal bebas didalam tubuh. ${ }^{5}$ Stres oksidatif pada mencit ditandai dengan terbentuknya radikal bebas. Efek radikal bebas dalam tubuh akan dinetralisir oleh antioksidan. Antioksidan dapat dibentuk oleh tubuh sendiri dan suplemen dari luar melalui makanan, minuman, dan obat-obatan, seperti vitamin $\mathrm{C}$, vitamin $\mathrm{E}$ dan lain-lain. ${ }^{6}$

Jus tomat mengandung antioksidan. Antioksidan (likopen, vitamin A dan vitamin C) pada jus tomat akan berikatan dengan radikal bebas sehingga mencegah radikal bebas berikatan dengan sel lain didalam tubuh. ${ }^{7}$

Tujuan penelitian ini ialah untuk mengetahui gambaran histologik ginjal tikus wistar yang diinduksi MSG dan gambaran histologik ginjal tikus wistar diberikan jus tomat setelah diinduksi dengan monosodium glutamat.

\section{METODE PENELITIAN}

Jenis penelitian ini Ialah eksperi-mental dengan post test only control group design. Sampel yang digunakan Ialah 15 ekor tikus wistar yang akan dibagi menjadi tiga kelompok: kelompok I tanpa perlakuan; kelompok II diberikan MSG dengan dosis 4 gr selama 14 hari; dan kelompok III diberikan jus tomat dengan dosis $3 \mathrm{ml}$ dan MSG dengan dosis 4 gr selama 14 hari. Terminasi dilakukan pada hari ke 15 . Setelah diterminasi, ginjal tikus difiksasi dan kemudian dicetak dalam blok parafin untuk dibuat preparat. Preparat diamati dengan menggunakan mikroskop cahaya.

\section{HASIL PENELITIAN}

Pada kelompok tanpa perlakuan atau hanya diberikan air minum dan pelet, menunjukkan gambaran histologik norma (Gambar 1).

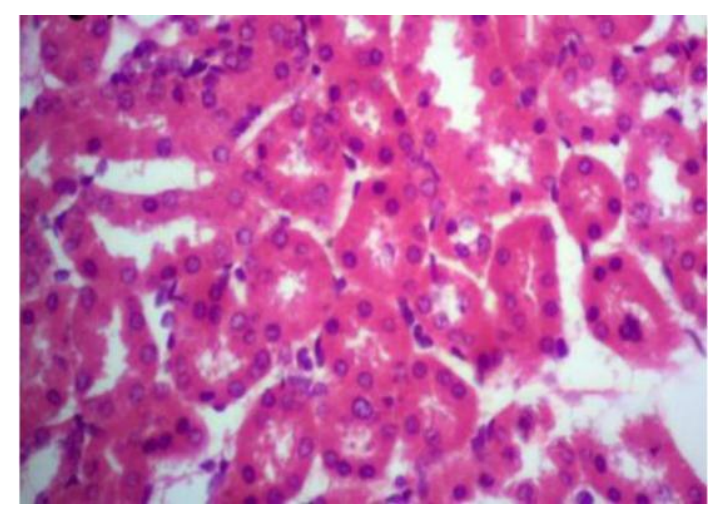

Gambar 1. Gambaran histologik ginjal tanpa perlakuan dengan pembesaran 10x100

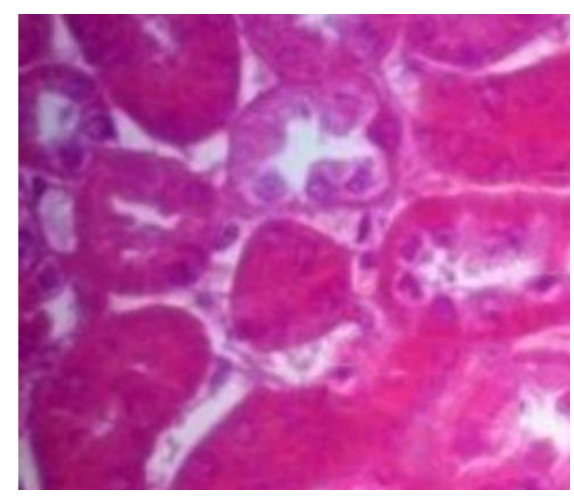

Gambar 2. Gambaran histologik ginjal dengan pemberian MSG dengan pembesaran 10x 100 


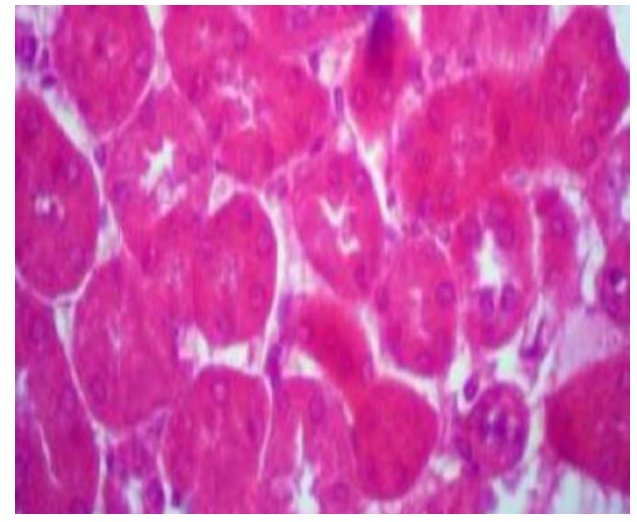

Gambar 3. Gambaran histologik ginjal dengan pemberian MSG dan jus tomat dengan pembesaran $10 \times 100$

Kelompok dengan pemberian MSG dan jus tomat menunjukkan gambaran histologik berupa glomerulus normal, pembengkakan epitel tubulus, dan penyempitan lumen (Gambar 3).

\section{BAHASAN}

Setelah dilakukan terminasi, dilakukan pengamatan pada gambaran makroskopik ginjal. Tidak terdapat perbedaan gambaran makroskopik ginjal antara kelompok tanpa perlakuan, kelompok dengan pemberian MSG dan kelompok dengan pemberian MSG dan jus tomat.Gambaran makroskopis yang didapatkan adalah normal, ginjal berwarna merah kecoklatan, konsistensi kenyal dan permukaan licin. ${ }^{8}$ Tidak terdapat perbedaan gambaran makroskopik ginjal antara kelompok tanpa perlakuan, kelompok dengan pemberian MSG dan kelompok dengan pemberian MSG dan jus tomat mungkin karena waktu penelitian yang tergolong singkat. Setelah dilakukan pembuatan preparat ginjal, kemudian dikukan pembacaan dengan menggunakan mikroskop.

Dari hasil pembacaan, kelompok perlakuan I memiliki gambaran yang hampir sama dengan kelompok perlakuan II, namun perlakuan I dan II memiliki gambaran yang berbeda dengan kelompok tanpa perlakuan. Gambaran mikroskopis yang didapatkan pada kelompok tanpa perlakuan adalah normal, sitoplasma pada tubulus berwarna merah muda, lumen yang jelas atau tidak menyempit, dan tidak ada tanda tanda radang. ${ }^{9}$

Gambaran mikroskopis kelompok perlakuan I dan kelompok perlakuan II ditemukan glomerulus normal, perubahan pada ginjal, epitel tubulus proksimal yang mengalami pembengkakan dan penyempitan lumen. Gambaran mikroskopis berupa sel-sel epitel tubulus proksimal yang membengkak dengan sitoplasma granuler karena terjadi pergeseran air ekstraseluler ke dalam sel. Pergeseran cairan ini terjadi karena adanya toksin yang menyebabkan perubahan muatan listrik pada permukaan sel epitel tubulus, perubahan transpor aktif ion dan asam organik, dan kemampuan mengkonsentrasikan dari ginjal yang akhirnya mengakibatkan tubulus rusak, aliran menurun. Gambaran pembengkakan sel ini disebut degenerasi albuminosa atau degenerasi parenkimatosa atau cloudy swelling (bengkak keruh), yang merupakan bentuk degenerasi yang paling ringan serta bersifat reversibel. Hal inilah yang mungkin menyebabkan lumen tubulus proksimal mengalami penyempitan hingga menutup. ${ }^{10}$

Kerusakan tubulus menyebabkan terganggunya proses rearbsorbsi dan sekresi. Jika proses rearbsorbsi terganggu maka zat yang masih dibutuhkan oleh tubuh tidak dapat diserap kembali oleh tubuh sehingga zat tersebut dapat keluar melalui urin. Dan jika proses sekresi terganggu maka zat zat yang tidak dibutuhkan oleh tubuh tidak dapat dikeluarkan melalui urin sehingga bersifat toksik yang dapat merusak organ ginjal. ${ }^{11}$

Jika suatu zat kimia disekresi secara aktif dari darah ke urin, zat kimia terlebih dahulu diakumulasikan dalam tubulus proksimal atau jika substansi kimia ini direabsorbsi dari urin maka akan melalui sel epitel tubulus dengan konsentrasi tinggi. Proses pemekatan tersebut mengakibatkan zat-zat toksik ini akan terakumulasi di ginjal dan menyebabkan kerusakan ginjal. ${ }^{10}$ Efek radikal bebas dalam tubuh akan dinetralisir oleh antioksidan. Antioksidan dapat dibentuk oleh tubuh sendiri dan suplemen dari luar. ${ }^{6}$

Kelompok perlakuan II memiliki 
gambaran yang hampir sama ataupun tidak menunjukkan perbedaan yang nyata dengan kelompok perlakuan I, dimana terdapat glomerulus normal, pembengkakan sel epitel tubulus, menyempitnya lumen tubulus, dan sitoplasma berwarna bening, namun epitel yang mengalami sedikit berkurang dibandingkan dengan kelompok kontrol positif. Hal ini mungkin karena dosis jus tomat yang terlalu sedikit sehingga tidak mampu membantu organ mengurangi radikal bebas. Tomat adalah buah yang mengandung antioksidan. Antioksidan pada tomat dapat membantu tubuh untuk mengurangi radikal bebas yang terdapat didalam tubuh. Antioksidan pada tomat akan menyumbangkan elektronnya berikatan dengan radikal bebas, sehingga radikal bebas tidak akan berikatan dengan sel lain, sehingga tidak menambah kerusakan pada organ. ${ }^{12}$

\section{SIMPULAN}

Berdasarkan hasil penelitian dapat disimpulkan bahwa gambaran histologik ginjal tikus wistar setelah diinduksi MSG baik dengan maupun tanpa pemberian jus tomat tidak berbeda nyata yaitu berupa glomeruli normal, pembengkakan sel-sel epitel tubuli, dan penyempitan lumen tubuli.

\section{SARAN}

1. Perlu dilakukan uji statistik untuk menilai dengan akurat persentasi dari kerusakan dan berkurangnya kerusakan yang terjadi.

2. Perlu dilakukan penelitian lebih lanjut dengan waktu yang lebih lama

\section{DAFTAR PUSTAKA}

1. The International Glutamate Information Service (IGIS), 2000. Safety of Monosodium Glutamate. [Online] Available from: http://www.glutamate.org[Accesed 18 September 2016].

2. Foods and Drugs Administration. FDA and
Monosodium Glutamate (MSG). 1995. [Online] Available from: http://vm.cfsan.fda.gov/lrd/msg.html[A ccessed18 September 2016].

3. Riset Kesehatan Dasar. 2007. [Online] [cited 18 September 2016]. Available from: http://labmandat.litbang.depkes.go.i /images/download/laporan/RKD/20 7/lap_rkd07.pdf.

4. Eweka AO. Histological studies of the effects of monosodium glutamate on the kidney of adult Wistar rats. The International Journal of Health. 2007;6(2).

5. Savira M. Gangguan Perkembangan Testis dan Penurunan Kadar Testosteron Pada Hewan Coba Akibat Paparan Monosodium Glutamate (MSG) Yang berlebihan [Tesis]. Medan: Fakultas Kedokteran Universitas Sumatera Utara; 2008.

6. Yusuf AM, Widodo JP, Doddy M, Soebadi. Hubungan radikal bebas dan antioksidan dengan kerusakan ginjal pada obstruksi akut. [Online] [cited 18 September 2016]. Available from: http://www.urologi.or.id.

7. Rao AV, Agarwal S. Role of lycopene as antioxidant carotenoid in the prevention of chronic diseases. Nutrition. 1999;19:305-323.

8. Sherwood Fisiologi Manusia: dari sel ke sistem. Jakarta: EGC, 2011.

9. Tambajong J. Sinopsis Histologi. Jakarta: ECG, 1995; p. 163.

10. Anggriani YW. Pengaruh pemberian teh Kombucha dosis bertingkat per oral terhadap gambaran histologi ginjal mencit BALB/C [Artikel Karya Tulis Ilmiah]. Semarang: Universitas Diponegoro; 2008.

11. Hasnisa, Unggul PJ, Arinto YW. Pengaruh paparan asap kendaraan bermotor terhadap gambaran histologi organ ginjal mencit (mus musculus). Jurnal UB Malang. 2015.

12. Haryatmi. Kemampuan Vitamin E Sebagai Antioksidan Terhadap Radikal Bebas Pada Lanjut Usia [Tesis]. Semarang: FKIP UMS; 2004. 